\title{
Exhaust emission characteristics of diesel and biodiesel
}

\author{
Yongmei Zhang ${ }^{1}$, Hongjun You ${ }^{2}$ \\ ${ }^{1}$ Liaoning Shihua University, Fushun, China; \\ ${ }^{2}$ SAIT Polytechnic, Calgary, Canada. \\ Email: youhongjun@hotmail.com
}

Received 20 June 2011; revised 6 September 2011; accepted 18 September 2011.

\begin{abstract}
The performances of diesel contrasted with that of biodiesel, such as $\mathrm{HC}$ and $\mathrm{CO}$ and $\mathrm{NO}_{\mathrm{x}}$ and fume and particles discharge, are studied on. The contents of $\mathrm{HC}, \mathrm{CO}, \mathrm{NO}_{\mathrm{x}}$ and flue gas are measured by Japan 163 Gas Chromatograph, USA 48 CO Analyser, Japan MEXA-7200H and FBY-201 flue gas analyzer, respectively. The experimental results shows $\mathrm{HC}$ discharge of biodiesel B20 decreases with the increase of rate of revolution; $\mathrm{NO}_{\mathrm{x}}$ discharge of biodiesel $\mathrm{B} 5$ and biodiesel $\mathrm{B} 20$ increase with the increase of torque; $\mathrm{NO}_{\mathrm{x}}$ discharge increases with the increase of adding biodiesel at the same torque; Flue gas discharge of biodiesel B5 and biodiesel B20 firstly increase and then decrease with the increase of torque; Particle discharge decreases with the increase of the amount of biodiesel.
\end{abstract}

Keywords: Biodiesel; Diesel; $\mathrm{HC}$ and $\mathrm{CO}$; Discharge Performance; Pollutants

\section{INTRODUCTION}

Biodiesel is the alkyl esters of long chain fatty acids and a transportation fuel that has gradually grown in popularity over the past decade. With the decreasing reserves of fossil fuels, it is now more important than ever to find transportation fuels that can serve as alternatives to crude oil-based fuels such as gasoline and diesel fuel. Common sources for biodiesel's feedstock include soybean oil [1], algal oil, higuereta oil [2], canola oil, vegetable oils [3], palm oil, corn oil [4], rapeseed oil [5], Brassica carinata oil [6], trap grease [7], yellow horn oil [8]. Lately there has been growing controversy about the use of potential food sources for the production of fuel. In attempt to address these concerns, researchers have turned their focus from the popular feedstock and are currently investigating the use of alternative feedstock such as beef fat from beef plant.

The objective of this work was to study on the discharge performance of biodiesel and diesel, such as HC and $\mathrm{CO}$ and $\mathrm{NO}_{\mathrm{x}}$ and flue gas and particles. And the experimental results of biodiesel are compared with that of diesel. The experimental results can prove that biodiesel has more competitive in price and environmental protection with diesel fuel.

\section{EXPERIMENT}

\section{Feedstock}

Diesel was obtained from Fushun Petrochemical Company. Biodiesel was produced from palm oil with Assistant of $\mathrm{CaO}-\mathrm{La}_{2} \mathrm{O}_{3}$. Properties of diesel and biodiesel are shown in Table 1 and Table 2, respectively.

\section{RESULTS AND DISCUSSION}

\subsection{CO and HC Discharge}

Experimental results of $\mathrm{CO}$ discharge at the different rate of revolution $(1000 \mathrm{r} / \mathrm{min}, 1500 \mathrm{r} / \mathrm{min}$ and $2000 \mathrm{r} / \mathrm{min})$

Table 1. Properties of diesel.

\begin{tabular}{cc}
\hline Project & Diesel \\
\hline Oxidation stability mg $100 \mathrm{~mL}^{-1}$ & 0.1 \\
Acidity mg KOH $100 \mathrm{~mL}^{-1}$ & 4.97 \\
$10 \%$ remain coke $\%$ & 0.01 \\
Copper corrosion & 1 \\
Kinematic viscosity $\left(20^{\circ} \mathrm{C}\right) \mathrm{mm}^{2} \cdot \mathrm{s}^{-1}$ & 3.541 \\
Freezing point ${ }^{\circ} \mathrm{C}$ & -37 \\
Flash point ${ }^{\circ} \mathrm{C}$ & 54 \\
Cetane number & 57 \\
\hline
\end{tabular}

Table 2. Properties of biodiesel.

\begin{tabular}{cc}
\hline Project & Biodiesel \\
\hline Density $\left(20^{\circ} \mathrm{C}\right) \mathrm{kg} \cdot \mathrm{m}^{-3}$ & 894.7 \\
Flash point ${ }^{\circ} \mathrm{C}$ & 121 \\
Sulfur content $\%$ & 0.0004 \\
Copper corrosion & 1 \\
Cetane number & 50.1 \\
\hline
\end{tabular}


are listed in Table 3. CO discharge of blank diesel has no change with the increase of rate of revolution. $\mathrm{CO}$ discharge of biodiesel B5 decreases with the increase of rate of revolution. But $\mathrm{CO}$ discharge of biodiesel B20 increases with the increase of rate of revolution. $\mathrm{CO}$ discharge decreases with the increase of adding biodiesel at the same rate of revolution.

The cylinder's temperature and the content of oxygen in the cylinder have a main effect on the burning degree of fuel. The content of $\mathrm{CO}$ shows if the burning degree of fuel is good or bad. When fuel is burnt, the content of oxygen determines to produce the amount of $\mathrm{CO}$ due to the high cylinder's temperature. Diesel doesn't almost consist of oxygen element, while biodiesel includes a little bit of oxygen element, so diesel requires more oxygen and discharges more $\mathrm{CO}$ than that of biodiesel.

Experimental results of $\mathrm{HC}$ discharge at the different rate of revolution are listed in Table 4. HC discharge of blank diesel and biodiesel B20 decreases with the increase of rate of revolution. But HC discharge of blank diesel firstly increase and then decreases with the increase of rate of revolution and has a maximum 5. HC discharge increases with the increase of adding biodiesel at the same rate of revolution.

Compound fuels (B5 and B20) have very low HC discharge because biodiesel has low content of aromatics and a little bit of oxygen element and high cetane number, so $\mathrm{HC}$ discharge is very low.

\section{2. $\mathrm{NO}_{\mathrm{x}}$ Discharge}

Experimental results of $\mathrm{NO}_{\mathrm{x}}$ discharge at $1000 \mathrm{r} / \mathrm{min}$ are shown in Table 5. $\mathrm{NO}_{\mathrm{x}}$ discharge of blank diesel and biodiesel B5 and biodiesel B20 increase with the increase of torque. $\mathrm{NO}_{\mathrm{x}}$ Discharge increases with the increase of adding biodiesel at the same torque. When biodiesel is added into diesel, it means more oxygen element is added into diesel, so NOx discharge gradually increases.

\subsection{Flue Gas Discharge}

Experimental results of flue gas discharge at $1000 \mathrm{r} / \mathrm{min}$ are shown in Table 6. Flue gas discharge of blank diesel and biodiesel DB5 and biodiesel DB20 firstly increase and then decrease with the increase of torque and have maximum. Flue gas discharge decreases with the increase of amount of biodiesel at the same torque. Flue gas decreases because $\mathrm{C} / \mathrm{H}$ of biodiesel is lower than that of diesel and density of biodiesel is more than that of diesel.

\subsection{Particle Discharge}

Experimental results of particle discharge at $1000 \mathrm{r} / \mathrm{min}$ are shown in Table 7. Particle discharge obviously decreases with the increase of adding biodiesel. Particle discharge of B5 and B20 decrease $8.2 \%$ and $13.3 \%$, respectively. Fuel is burnt to discharge particle due to high temperature and no oxygen and crack reaction. Compound fuels (B5 and B20) have low content of aromatics to produce less particle and high cetane number to decrease the burning period and the burning retention, so it prevents more particle producing.

Table 3. Results of CO discharge.

\begin{tabular}{clcc}
\hline $\begin{array}{c}\text { Rate of revolution } \\
\text { r/min }\end{array}$ & 1000 & 1500 & 2000 \\
\hline Torque Nm & 300 & 300 & 300 \\
& CO discharge $\%$ & \\
Blank diesel (B0) & 0.01 & 0.01 & 0.01 \\
Biodiesel (B5) & 0.01 & 0.01 & 0.008 \\
Biodiesel (B20) & 0.006 & 0.007 & 0.008 \\
\hline
\end{tabular}

Table 4. Results of HC discharge.

\begin{tabular}{cccc}
\hline $\begin{array}{c}\text { Rate of revolution } \\
\text { r/min }\end{array}$ & 1000 & 1500 & 2000 \\
\hline Torque Nm & 300 & 300 & 300 \\
& HC discharge ugg & \\
Blank diesel (B0) & 18 & 14 & 12 \\
Biodiesel (B5) & 6 & 7 & 4 \\
Biodiesel (B20) & 9 & 8 & 7 \\
\hline
\end{tabular}

Table 5. Effect of different torque on $\mathrm{NO}_{\mathrm{x}}$ discharge $\left(\mathrm{ugg}^{-1}\right)$ at $1000 \mathrm{r} / \mathrm{min}$.

\begin{tabular}{ccccc}
\hline & $100 \mathrm{Nm}$ & $150 \mathrm{Nm}$ & $200 \mathrm{Nm}$ & $250 \mathrm{Nm}$ \\
\hline Blank diesel (B0) & 875 & 1345 & 2051 & 2178 \\
Biodiesel (B5) & 891 & 1357 & 2067 & 2207 \\
Biodiesel (B20) & 886 & 1506 & 2178 & 2298 \\
\hline
\end{tabular}

Table 6. Effect of different torque on flue gas discharge (\%) at $1000 \mathrm{r} / \mathrm{min}$.

\begin{tabular}{ccccc}
\hline & $100 \mathrm{Nm}$ & $150 \mathrm{Nm}$ & $200 \mathrm{Nm}$ & $250 \mathrm{Nm}$ \\
\hline Blank diesel (B0) & 0.78 & 1.18 & 1.08 & 1.04 \\
Biodiesel (B5) & 0.77 & 1.10 & 0.98 & 0.94 \\
Biodiesel (B20) & 0.60 & 0.82 & 0.48 & 0.40 \\
\hline
\end{tabular}

Table 7. Particles discharge.

\begin{tabular}{cc}
\hline Project & Results \\
\hline $\begin{array}{c}\text { Rate of revolution } \\
\text { Torque Nm }\end{array}$ & 1000 \\
& 300 \\
Dilution $\mathrm{PM} / \mathrm{mgh}^{-1}$ & \\
Blank diesel (B0) & 6.67 \\
Biodiesel (B5) & 6.12 \\
Biodiesel (B20) & 5.78 \\
\hline
\end{tabular}




\section{CONLUSION}

Biodiesel discharge performance, such as $\mathrm{HC}$ and $\mathrm{CO}$ and $\mathrm{NO}_{\mathrm{x}}$ and flue gas and particles discharge, is researched. The experimental results are as follow:

1) Adding biodiesel is benefit to decrease pollutants in the environment.

2) CO discharge decreases with the increase of adding biodiesel at the same rate of revolution and $\mathrm{HC}$ discharge increases with the increase of adding biodiesel at the same rate of revolution.

3) $\mathrm{NO}_{x}$ discharge of blank diesel and biodiesel $\mathrm{B} 5$ and biodiesel B20 increase with the increase of torque. $\mathrm{NO}_{x}$ Discharge increases with the increase of adding biodiesel at the same torque.

4) Flue gas discharge of blank diesel and biodiesel B5 and biodiesel B20 firstly increase and then decrease with the increase of torque and have maximum. Flue gas Discharge decreases with the increase of amount of biodiesel at the same torque.

5) Particle discharge decreases with the increase of adding biodiesel.

\section{REFERENCES}

[1] Sonam, M., Samir, K.K. and David, G.B. (2006) Standard biodiesel from soybean oil by a single chemical reaction. Jaocs, 83, 641-644. doi:10.1007/s11746-006-1251-6

[2] Ramon, P.R., Roger, S. and Sebastian, V. (2009) Thermal and kinetic evaluation of biodiesel derived from soybean oil and higuereta. Journal Thermal Analyses, 96, 897-901. doi:10.1007/s10973-009-0043-2

[3] Rafael, C.R., Giandra, V., Keiko, W. and Marco, A. (2008) Enzymatic synthesis of biodiesel from transesterification reactions of vegetable oils and short chain alcohols. Journal of Oil Chemistry and Society, 85, 925-930. doi:10.1007/s11746-008-1284-0

[4] Hossein, N., Santosh, R.P.B. and Emily, A.G. (2009) A novel method for the production of biodiesel from the whole stillage-extracted corn oil. Journal of Oil Chemistry and Society, 86, 83-91. doi:10.1007/s11746-008-1318-7

[5] Tao, W., Ping, Y., Shangkun, G., Qiang, L. and Yunbai, L. (2008) Application of $\mathrm{KF} / \mathrm{MgO}$ as a heterogeneous catalyst in the production of biodiesel from rapeseed oil. Korean Journal Chemical Engineering, 25, 998-1003. doi:10.1007/s11814-008-0161-8

[6] Gemma, V., Mercedes, M. and José, A. (2005) Optimization of brassica carinata oil methanolysis for biodiesel production. JAOCS, 82, 899-904. doi:10.1007/s11746-005-1162-6

[7] Zhongming, W., Jinsuk, L., Jiyeon, P., Chuangzhi, W. and Zhenhong, Y. (2008) Optimization of biodiesel production from trap grease via acid catalysis. Korean Journal Chemical Engineering, 25, 670-674. doi:10.1007/s11814-008-0110-6

[8] Yu, F., Yuan, Z., Lili, W., Nai, Z., Wei, L., Shuang, L. and Zhang, S. (2008) Determination of fatty acid methyl esters in biodiesel produced from yellow jorn oil by LC. Chromatography, 67, 10-14. 